\title{
Analisis Faktor-Faktor Yang Mempengaruhi Cadangan Devisa Indonesia
}

\author{
Laeli Lafi Khusnatun ${ }^{1}$ \\ Jurusan Ekonomi Pembangunan, Fakultas Ekonomi, Universitas Tidar \\ laelilafikhusnatun26@gmail.com \\ Dinar Melani Hutajulu² \\ Jurusan Ekonomi Pembangunan, Fakultas Ekonomi, Universitas Tidar \\ dinarmelani@untidar.ac.id
}

\begin{abstract}
Abstrak
Cadangan devisa merupakan bagian penting dari perekonomian suatu negara. Besar kecilnya cadangan devisa dapat dipengaruhi oleh nilai ekspor. Tujuan dari penelitian ini yaitu menganalisis pengaruh ekspor, inflasi, BI rate, dan Utang Luar Negeri (ULN) terhadap cadangan devisa, serta menganalisis hubungan kointegrasi antara ekspor, inflasi, BI rate, dan utang luar negeri terhadap cadangan devisa. Penelitian ini menggunakan data sekunder dengan bentuk data time series. Analisis data yang digunakan adalah Error Correction Model (ECM) menggunakan aplikasi Eviews10. Hasil penelitian ini menujukan bahwa yang mempengaruhi cadangan devisa adalah $\mathrm{BI}$ Rate dan ULN, serta keseimbangan jangka pendek mempengaruhi keseimbangan jangka panjang.
\end{abstract}

Kata Kunci: Cadangan Devisa, Utang Luar Negeri, Inflasi, BI Rate, Keseimbangan

\section{Abstract}

Foreign exchange reserves are an important part of a country's economy. The size of foreign exchange reserves can be influenced by the value of exports. The purpose of this study is to analyze the effect of exports, inflation, BI rate, and External Debt (ULN) on foreign exchange reserves, as well as analyze the cointegration relationship between exports, inflation, $B I$ rate, and foreign debt on foreign exchange reserves. This study uses secondary data in the form of time series data. Analysis of the data used is the Error Correction Model (ECM) using the Eviews 10 application. The results of this study indicate that those that affect foreign exchange reserves are the $\mathrm{BI}$ Rate and external debt, and the short-term balance affects the long-term balance.

Keywords: Foreign exchange reserves, Foreign debt, Inflation, BI Rate, Balance

\section{PENDAHULUAN}

Cadangan menggambarkan perekonomian dalam rangka pembangunan sektor ekonomi di suatu negara. Cadangan devisa merupakan bagian penting dari perekonomian, terutama bagi negaranegara yang menganut sistem ekonomi terbuka yaitu melakukan hubungan internasional seperti ekspor dan impor dengan negara lain sehingga kebutuhan pokok masyarakat dapat terpenuhi. Oleh karena itu devisa sangat dibutuhkan untuk membiayai pembangunan industri dalam negeri. Menurut Bank Indonesia, utang luar negeri dan pendapatan pajak dari tahun 2016 hingga 2020 akan berdampak besar pada cadangan devisa Indonesia (Ulya, 2021). Menurut UU 
Keuangan Negara, batas aman hutang negara terhadap Produk Domestik Bruto (PDB) maksimal $60 \%$. Berdasarkan data Bank Indonesia (BI), Indonesia memiliki utang khususnya utang luar negeri sebesar US $\$ 417,5$ miliar atau mengalami peningkatan $3,5 \%$ yoy pada akhir tahun 2020, serta $39,4 \%$ terhadap Produk Domestik Bruto yang dimiliki Indonesia. Begitu juga utang luar negeri dan pendapatan pajak mempengaruhi peningkatan devisa Indonesia. Debuti Gubernur Senior BI mengatakan ekspor yang telah dilakukan Indonesia jauh lebih rendah dibandingkan dengan utang yang dimiliki Indonesia, namun utang ini masih tergolong aman. Oleh karena itu, agar banyak devisa yang bersumber dari aktivitas ekspor dan utang Indonesia lebih sehat maka diperlukan peningkatan ekspor ke luar negeri (Deny, 2017).

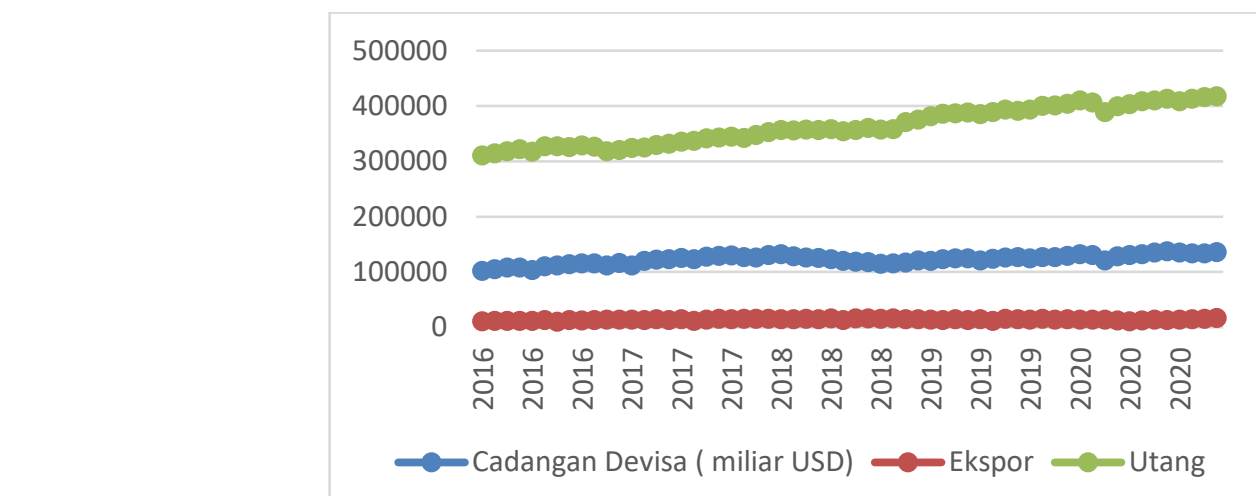

Gambar 1. Perkembangan Cadangan Devisa, Ekspor, dan Utang Luar Negeri dari Tahun 2016-2020 Sumber : Bank Indonesia, data diolah (2021)

Cadangan devisa Indonesia selama 5 tahun terakhir mengalami fluktuasi. Pada bulan Januari 2016 Bank Indonesia mencatat sebesar 102,1 miliar dolar AS merupakan terendah selama 5 tahun terakhir yaitu dari tahun 2016 sampai 2020. Menurut Direktur Departemen Komunikasi Bank Indonesia (2016), cadangan devisa Indonesia level terendah pada bulan Januari 2016 karena kebutuhan untuk membayar utang luar negeri yang didalamnya termasuk utang dan beserta bunga yang sudah jatuh tempo. Sepanjang sejarah devisa Indonesia bulan Desember 2020 merupakan tertinggi kedua yaitu sebesar 135,9 miliar dolar AS, serta mengalami peningkatan setelah mengalami penurunan selama 3 bulan (Bank Indonesia, 2021).

Aktivitas ekspor yang dilakukan suatu negara merupakan salah satu sumber cadangan devisa di negara tersebut. Keterkaitan antara ekspor dengan cadangan devisa adalah ketika ekspor lebih rendah dari impor maka akan menurunkan cadangan devisa, sebaliknya apabila ekspor lebih tinggi dibandingkan dengan impor maka cadangan devisa di negara tersebut akan mengalami penambahan.

Tujuan penelitian ini berdasarkan latar belakang yang telah dijelaskan tersebut adalah sebagai berikut:

1. Menganalisis pengaruh jangka panjang maupun jangka pendek pada ekspor dan cadangan devisa.

2. Menganalisis pengaruh jangka panjang maupun jangka pendek utang luar negeri dan cadangan devisa.

3. Menganalisis pengaruh jangka panjang maupun jangka pendek inflasi terhadap cadangan devisa. 
4. Menganalisis pengaruh jangka panjang maupun jangka pendek BI rate terhadap cadangan devisa.

Sedangkan manfaat penelitian ini adalah sebagai sumber pengambilan keputusan kebijakan perdagangan internasional yang dilakukan oleh pemerintah, sebagai sumber pengetahuan masyarakat mengenai hubungan perdagangan internasional dan cadangan devisa, dan sebagai sumber referensi yang lebih baik untuk penelitian selanjutnya.

\section{KAJIAN PUSTAKA}

\section{Cadangan Devisa}

Krugman (2003) berpendapat bahwa cadangan devisa adalah aset luar negeri yang dikendalikan bank sentral sebagai jasa pamungkas untuk menghadapi kesulitan ekonomi nasional (Krugman \& Obtfel, 2003). Menurut Palembangan (2020) cadangan devisa (foreign currency liquidity) merupakan semua aset luar negeri yang digunakan setiap saat untuk mengatasi ketidakseimbangan neraca pembayaran atau dengan kata lain untuk stabilitas moneter suatu negara dan dikuasai oleh otoritas moneter dalam negeri (Palembangan et al., 2020). Sehingga disimpulkan bahwa cadangan devisa adalah suatu alat pembayaran dalam perdagangan internasional dalam bentuk valuta asing yang dikelola oleh bank sentral yang ada di dalam negeri yang dapat digunakan untuk menjaga stabilitas moneter, tabungan nasional, dan pembayaran utang.

\section{Ekspor dan Hubungannya Terhadap Cadangan Devisa}

Ekspor adalah aktivitas menjual barang ke luar negeri sesuai dengan peraturan yang berlaku di negara pengekspor maupun pengimpor, serta barang tersebut merupakan hasil produksi dalam negeri negara. Menurut Asyaria (2020) ekspor yaitu aktivitas perdagangan internasional yang dapat mendorong kemajuan negara yang melakukan ekspor terutama bagi negaranegara berkembang (Asyaria et al., 2020). Ketika suatu negara meningkatkan ekspor, negara tersebut akan menerima pendapatan berupa devisa, yang kemudian akan dikelola oleh bank sentral, atau menambah cadangan devisa. Sesuai dengan penelitian Jalunggono (2020) yaitu ekspor berdampak positif dan signifikan terhadap cadangan devisa (Jalunggono et al., 2020).

\section{Inflasi dan Hubungannya Terhadap Cadangan Devisa}

Inflasi merupakan tren kenaikan harga produk secara keseluruhan. Kenaikan harga sejumlah kecil barang dan jasa tidak dianggap sebagai inflasi. Menurut Nopirin pada bukunya, inflasi mempengaruhi pendapatan, efisiensi, dan output (Nopirin, 2012). Menurut Boediono (2001), ia berpendapat bahwa jika tingkat inflasi domestik tinggi, harga barang dan jasa akan meningkat, sehingga menghambat kegiatan ekonomi (Juliansyah et al., 2020). Artinya, diperlukan lebih banyak cadangan devisa untuk transaksi eksternal (transaksi luar negeri). Oleh karena itu, hubungan antara tingkat inflasi dan cadangan devisa adalah berdampak negatif.

\section{BI Rate dan Hubungannya Terhadap Cadangan Devisa}

Suku bunga $\mathrm{BI}$ atau sering disebut dengan Bl Rate merupakan acuan dalam menentukan suku bunga yang dapat mencerminkan posisi atau stance kebijakan moneter yang ditetapkan oleh bank Indonesia kemudian diumumkan kepada publik (Bank Indonesia, 2017). Bank-bank umum Indonesia menggunakan suku bunga $\mathrm{BI}$ ini sebagai suku bunga acuan mereka. Menurut 
Mankiw (2000) ketika bunga terjadi peningkatan, maka modal kerja menurun karena ada penambahan biaya pengembalian utang, menyebabkan eksportir mengurangi pinjaman yang mengarah pada penurunan ekspor. Ketika suku bunga naik, investasi lebih banyak dilakukan oleh masyarakat, yang akan meningkatkan output dan ekspor (Mankiw, 2000). Menurut Juliansyah dalam penelitiannya, menunjukkan bahwa hal yang mengakibatkan ketika pasar keuangan mengalami gejolak yang diakibatkan oleh suku bunga yang meningkat, serta dengan meningkatnya suku bunga juga dapat berakibat pada banyaknya pinjaman yang masuk dalam hal ini modal asing yang masuk ke dalam negeri (Juliansyah et al., 2020). Modal asing yang masuk dalam bentuk pinjaman ini akan secara langsung berdampak pada meningkatkan cadangan devisa atau berpengaruh positif, begitu pun sebaliknya ketika pinjaman menurun dapat menurunkan cadangan devisa.

\section{Utang Luar Negeri dan Hubungannya Terhadap Cadangan Devisa}

Adiyadna (2017) berpendapat bahwa utang luar negeri merupakan modal suatu negara yang diperoleh kreditur di luar negeri, seperti diperoleh dari bank swasta di luar negeri, pemerintah luar negeri, serta IMF dan Bank Dunia (World Bank) sebagai lembaga keuangan internasional (Adiyadnya, 2017). Pinjaman yang diperoleh dari pemerintah luar negeri digunakan sebagai pembangunan di dalam negeri, pembiayaan negara, dan pembiayaan impor. Sedangkan pinjaman yang diperoleh dari swasta digunakan oleh perseorangan dan badan untuk aktivitas ekspor dan impor dalam perusahaan. Menurut Ardianti dan Swara (2018) bahwa peningkatan pinjaman yang berasal dari luar negeri dapat berakibat pada neraca modal yang meningkat juga neraca pembayaran (Ardianti \& Swara, 2018).

\section{Penelitian Terdahulu}

Penulis dalam melakukan penelitian menggunakan acuan atau referensi penelitian sebelumnya yang telah dilakukan. Berikut ini adalah penelitian-penelitian terdahulu berupa artikel terkait dengan penelitian yang dilakukan penulis. Menurut penelitian Ardianti dan Swara (2018) tentang "Pengaruh Ekspor Neto, Kurs, Produk Domestik Bruto, dan Utang Luar Negeri Terhadap Cadangan Devisa Indonesia 1997-2016" dimana yang tidak berpengaruh signifikan terhadap cadangan devisa tahun 1997-2016 adalah variabel ekspor neto, kurs, dan PDB, sebaliknya yang berpengaruh signifikan terhadap cadangan devisa tahun 1997-2016 adalah variabel ULN yang dilihat dari hasil uji yang telah dilakukan yaitu thitung lebih besar dari ttabel. Serta hasil analisis standardizes coefficient beta, yang paling besar pengaruhnya terhadap cadangan devisa adalah utang luar negeri (Ardianti \& Swara, 2018).

$$
\text { Menurut penelitian Adiyadna }
$$
(2017) mengenai "Analisis Pengaruh Inflasi, Kurs Dolar Amerika, Suku Bunga Kredit, dan Utang Luar Negeri Terhadap Cadangan Devisa Tahun 1996-2015" menunjukkan bahwa variabel inflasi tidak berdampak pada cadangan devisa pada tahun 1996-2015, dikarena mata uang rupiah Indonesia tahun 1996-2015 terapresiasi selama yaitu akibat dari penurunan harga komoditas ekspor, fluktuasi nilai tukar dolar AS selama periode 1996-2015 sehingga tidak berdampak signifikan, serta suku bunga kredit berdampak negatif signifikan yang artinya kenaikan suku bunga berakibat pada cadangan devisa berkurang. Sedangkan utang luar negeri berdampak 
positif dan signifikan terhadap cadangan devisa pada tahun 1996-2015 yang artinya kenaikan cadangan devisa pada tahun 1996-2015 diakibatkan oleh utang luar negeri yang meningkat (Adiyadnya, 2017).

Menurut penelitian Jalunggono, Yulia, dan Whinarko (2020) mengenai "Pengaruh Ekspor, Impor, dan Kurs Terhadap Cadangan Devisa Indonesia Periode 2004-2018" yaitu ekspor dan nilai tukar berdampak positif signifikan terhadap cadangan devisa pada tahun 2004-2018, sedangkan variabel impor tidak berpengaruh signifikan terhadap cadangan devisa pada tahun 2004 sampai pada tahun 2018. Ekspor pada tahun 2004-2018 mempengaruhi cadangan devisa karena salah satunya mampu meningkatkan 15\% cadangan devisa pada tahun 2011 dengan nilai ekspor US\$203.496 juta (Jalunggono et al., 2020).

Dalam penelitian Palembangan, Robby, dan Dennij (2020) mengenai "Analisis Pengaruh Tingkat Bunga Acuan BI, Sibor, dan Nilai Tukar Rupiah Terhadap Cadangan Devisa di Indonesia (2011:Q1-2019:Q4)" menggunakan model Error Correction Model (ECM) dimana tingkat bunga acuan $\mathrm{BI}$ (BI Rate) tidak berdampak pada cadangan devisa di Indonesia dalam jangka pendek, tetapi berdampak negatif terhadap cadangan devisa Indonesia dalam jangka pendek yang berarti setiap kenaikan suku bunga acuan $\mathrm{BI}$ akan mengurangi cadangan devisa Indonesia. Sibor tidak berpengaruh terhadap cadangan devisa Indonesia dalam jangka pendek, tetapi berdampak positif terhadap cadangan devisa Indonesia dalam jangka panjang. Koefisien Sibor dalam jangka panjang dan jangka pendek positif yang artinya setiap kenaikan Sibor akan meningkatkan cadangan devisa. Sedangkan kurs (nilai tukar) berpengaruh negatif terhadap cadangan devisa, namun dalam jangka panjang tidak berpengaruh terhadap cadangan devisa (Palembangan et al., 2020).

Menurut penelitian Juliansyah, Putri, dan Apridar (2020) mengenai "Analisis Faktor-Faktor Yang Mempengaruhi Cadangan Devisa Indonesia Bukti (Kointegrasi dan Kausalitas)" melalui uji kointegrasi dengan Bounds Test terdapat hubungan jangka panjang atau hubungan kointegrasi antar variabel cadangan devisa, kurs, inflasi, ekspor, dan BI Rate. Pada uji kausalitas Granger variabel cadangan devisa dan ekspor, cadangan devisa dan kurs, dan $\mathrm{BI}$ Rate dan cadangan devisa saling memiliki hubungan satu arah antara. Hasil estimasi jangka pendek, ekspor memiliki dampak yang positif signifikan terhadap cadangan devisa. Nilai tukar dan BI Rate berdampak negatif signifikan terhadap cadangan devisa. Serta variabel inflasi tidak memiliki pengaruh pada cadangan devisa selama periode ini. Sedangkan estimasi jangka panjang, hanya $\mathrm{BI}$ Rate yang berdampak negatif signifikan terhadap cadangan devisa pada periode ini (Juliansyah et al., 2020).

\section{Kerangka Pemikiran}

Jumlah cadangan devisa sering mengalami perubahan hal tersebut dapat dipengaruhi oleh ekspor, inflasi, BI rate, dan utang luar negeri. Karena dengan meningkatnya ekspor maka negara akan menerima pendapatan dari hasil kegiatan ekspor tersebut, sehingga cadangan devisa juga akan meningkat. Peningkatan pinjaman luar negeri akan berdampak pada peningkatan cadangan devisa dalam negeri. Sedangkan ketika inflasi tinggi akan berdampak buruk pada perdagangan internasional karena terjadi kenaikan harga-harga sehingga tidak mungkin untuk bersaing di pasar internasional. Hal ini menyebabkan penurunan ekspor, sehingga berakibat 
pada cadangan devisa yang menurun. Jika suku bunga mengalami kenaikan maka akan mendorong menurunnya investasi sehingga akan menurunkan pendapatan pendapatan agregat. Hal ini dapat menurunkan impor (ekspor lebih besar dari impor) menyebabkan surplus neraca perdagangan dan meningkatkan cadangan devisa.

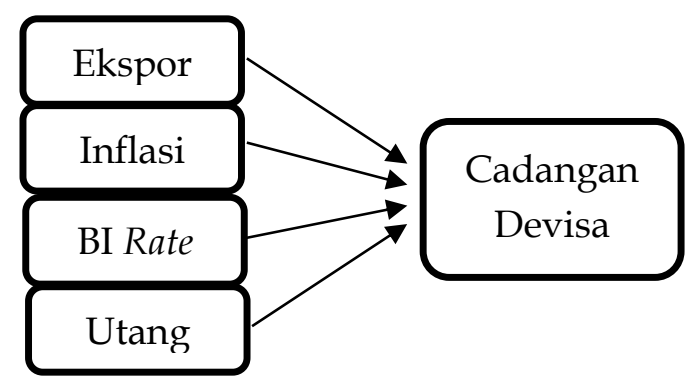

\section{METODE PENELITIAN}

Penelitian ini, data yang digunakan yaitu data runtut waktu (time series) selama 5 tahun (2016-2020). Data sekunder yang diperoleh dari laporan Bank Indonesia (BI) dan laporan Badan Pusat Statistik (BPS) merupakan sumber data dalam penelitian ini. Cadangan devisa merupakan variabel dependen yang digunakan dalam penelitian ini, sedangkan ekspor, inflasi, BI rate, dan utang luar negeri merupakan variabel independennya.

Error Correction Model (ECM) merupakan metode analisis yang digunakan dalam penelitian ini. Error Correction Model (ECM) digunakan untuk mengatasi masalah data time series yang tidak stasioner (Windarjono, 2018). Serta dapat menganalisis hubungan jangka pendek dan jangka panjang variabel dependen dan variabel independennya.

\section{Uji Stasioneritas (Unit Root Test)}

Saat menguji stasioneritas data dalam penelitian ini, menggunakan uji yang dikembangkan oleh Dickey-Fuller dengan nama uji akar unit Dickey-Fuller (DF). Pada uji stasioneritas (uji DickeyFuller) langkah pertama menguji pada tingkat level. Apabila data tidak stasioner, dapat dilanjutkan dengan level pada level berbeda yaitu pada tingkat $1^{\text {st }}$ different atau $2^{\text {nd }}$ different. Membandingkan nilai absolut statistik ADF dengan nilai kritis Mackinnon merupakan langkah dalam menentukan data stasioner atau tidak. Jika nilai absolut statistic ADF lebih besar dengan nilai kritis tersebut maka data yang diuji stasioner.

\section{Uji Kointegrasi}

Uji kointegrasi berguna untuk mengetahui apakah variabel dalam model memiliki hubungan keseimbangan jangka panjang atau tidak. Uji yang dilakukan menggunakan metode uji Engle-Granger (EG) yaitu dengan cara memanfaatkan uji Augmented Dickey-Fuller dengan mengestimasi model regresi dengan menghitung nilai residualnya. Untuk mengetahui apakah model regresi terkointegrasi atau memiliki hubungan jangka panjang yaitu apabila nilai residualnya stasioner atau nilai statistiknya lebih besar dari nilai kritisnya.

\section{Error Correction Model (ECM)}

Langkah selanjutnya setelah uji kointegrasi atau memiliki hubungan jangka panjang yaitu dengan estimasi ECM. Syarat melakukan estimasi ECM adalah jika data stasioner pada tingkat yang sama dan tidak stasioner pada tingkat level serta adanya kointegrasi antar variabel. Adapun persamaannya sebagai berikut (Windarjono, 2018):

$$
\text { Dimana: }
$$

$$
\Delta Y_{t}=\alpha_{0}+\alpha_{1} \Delta X_{t}+\alpha_{2} E C T+e_{t}
$$

$\mathrm{Y} \quad=$ Variabel yang diamati

Ect $=$ Error Correction Term $\left(\mathrm{e}_{\mathrm{t}-1}\right)\left(\mathrm{Y}_{\mathrm{t}-1}-\right.$ $\left.\beta_{0}-\beta_{1} X_{t-1}\right)$

$\alpha_{0}=$ Konstanta

$\alpha_{1}=$ koefisien jangka pendek

$\mathrm{t} \quad=$ Time trend (trend waktu)

Dalam hal ini koefisien jangka pendek yaitu koefisien $\boldsymbol{\alpha}_{1}$ sedangkan koefisien jangka panjangnya yaitu $\beta_{1}$. 
Untuk menjelaskan seberapa cepat waktu diperlukan untuk mendapatkan nilai keseimbangan dapat dilihat dari koefisien koreksi ketidakseimbangan $\alpha_{2}$ dalam bentuk nilai absolut. Adapun persamaan ECM yang digunakan dalam penelitian ini sebagai berikut :

$$
\begin{aligned}
\Delta Y_{t}=\beta_{0}+ & \beta_{1} \Delta X 1_{t}+\beta_{2} \Delta X 2_{t}+\beta_{3} \Delta X 3_{t} \\
& +\beta_{4} \Delta X 4_{t}+\beta_{5} E C T+e_{t}
\end{aligned}
$$$$
\text { Dimana : }
$$

$\Delta \mathrm{Y}_{\mathrm{t}}=$ Perubahan cadangan devisa

$\Delta \mathrm{X} 1_{\mathrm{t}}=$ Perubahan ekspor (miliar dollar

AS)

$\Delta \mathrm{X} 2 \mathrm{t}=$ Perubahan inflasi (persen)

$\Delta \mathrm{X} 3_{\mathrm{t}}=$ Perubahan $\mathrm{BI}$ Rate (persen)

$\Delta \mathrm{X} \mathrm{t}_{\mathrm{t}}=$ Perubahan Utang Luar Negeri (miliar dollar AS)

$\mathrm{ECT}=$ Error Correctiom Term (et-1)

\section{HASIL DAN PEMBAHASAN Analisis Deskriptif}

\section{Perubahan Cadangan Devisa}

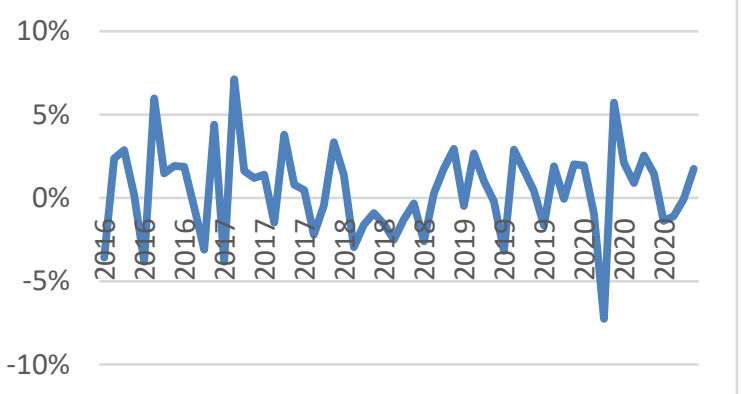

Gambar 2. Perubahan Cadangan Devisa Indonesia Tahun 2016-2020

Sumber: Bank Indonesia, data diolah (2021)

Gambar 2 menunjukkan bahwa perubahan cadangan devisa mengalami fluktuasi. Pada bulan Januari 2016 Bank Indonesia mencatat sebesar 102,1 miliar dolar AS merupakan terendah selama 5 tahun terakhir yaitu dari tahun 2016 sampai 2020. Menurut Direktur Departemen Komunikasi Bank Indonesia (2016), hal ini dipengaruhi oleh permintaan devisa yang digunakan untuk membayar utang luar negeri pemerintah, termasuk pembayaran utang pokok beserta bunga global bond yang jauh tempo. Pada akhir Desember 2020 cadangan devisa Indonesia sebesar 135,9 miliar dolar AS, meningkat setelah 3 bulan mengalami penurunan (BI, 2021). Peningkatan ini cukup besar, mencapai level tertinggi kedua dalam sejarah. Cadangan devisa ini lebih tinggi dari rasio kecukupan internasional selama 3 bulan impor, sehingga dapat digunakan untuk menjaga stabilitas makroekonomi dan sistem keuangan dan ketahanan sektor eksternal dan (Pransuamitra, 2021).

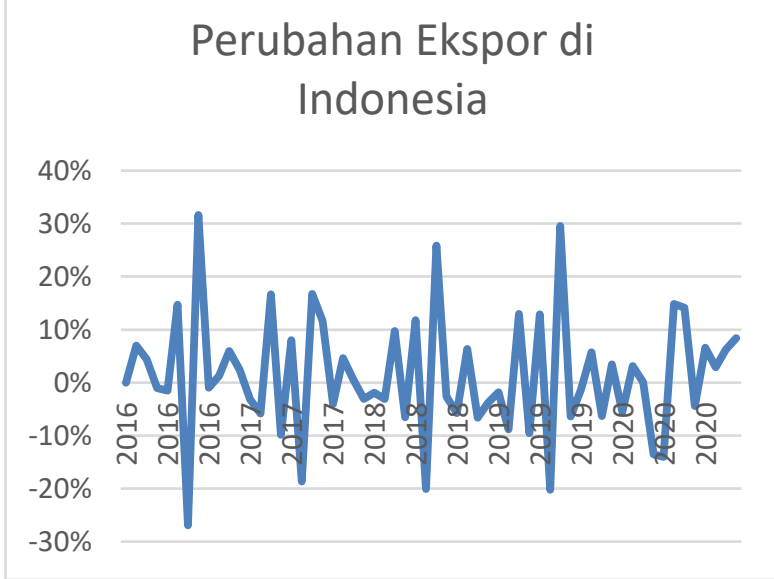

Gambar 3. Perubahan Ekspor Indonesia Tahun 2016-2020

Sumber: Badan Pusat Statistik, data diolah (2021)

Gambar 3 menggambarkan perubahan ekspor di Indonesia selama 5 tahun. Penurunan ekspor terbesar pada bulan Juli 2016 sebesar -27 persen. Hal ini disebabkan oleh faktor perlambatan ekonomi global yang mempengaruhi permintaan ekspor, faktor lain yaitu libur lebaran yang menyebabkan banyak perusahaan menghentikan produksi dan pengiriman barang. Namun pada bulan Agustus 2016 mengalami peningkatan yang cukup signifikan sebesar 32 persen. Pada bulan Juli 2018 nilai ekspor tertinggi selama 5 tahun terakhir yaitu pada posisi sebesar 18,30 miliar dolar AS, ini disebabkan faktor musiman lebaran pada bulan Juni 2018 yang membatasi ekspor. Pada bulan Mei 2020, nilai ekspor terendah selama 5 tahun terakhir yaitu sebesar 8,44 Miliar dolar AS atau turun 
$13,40 \%$ bila dibandingkan dengan bulan April 2020. Hal ini disebabkan oleh pandemic Corona Viruse Disease 19 (Covid-19) yang melanda berbagai mitra dagang Indonesia. Karena banyak negara mengalami kontraksi akibat pembatasan sosial yang diterapkan, penurunan daya beli, dan masalah lainnya. Pada bulan Desember 2020, nilai ekspor meningkat menjadi 14,44 Miliar dolar AS, ini merupakan tertinggi sepanjang tahun 2020 .

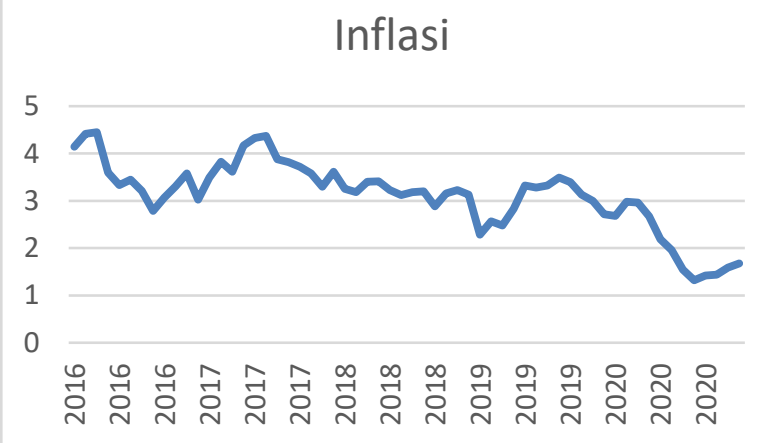

Gambar 4. Perkembangan Inflasi Indonesia Tahun 2016-2020

Sumber: Badan Pusat Statistik, data diolah (2021)

Gambar 4 menggambarkan perkembangan inflasi di Indonesia selama 5 tahun yang berfluktuasi. Inflasi tertinggi yaitu bulan Maret 2016 sebesar 4,45 persen disebabkan oleh kenaikan harga bahan-bahan pangan terutama harga bawang merah, cabai merah, dan cabai rawit. Pada bulan Agustus 2016 inflasi mencapai 2,79 persen menurun dari bulan April 2016. Penurunan harga pada Agustus 2016 berasal dari harga komoditas ayam negeri, wortel, bawang merah, beras, dan daging sapi. Bulan Agustus 2020 merupakan deflasi terendah sejak tahun 2000. Hal ini disebabkan oleh Covid-19, berbagai negara menunjukkan perlambatan inflasi dan bahkan mengarah ke deflasi. Komoditas yang mendorong terjadinya inflasi pada bulan Agustus 2020 paling tinggi adalah daging ayam negeri, telur ayam negeri, tomat, bawang merah, jeruk, dan pisang. Selain itu, komoditas tarif angkutan udara juga menyumbang deflasi pada bulan Agustus 2016.

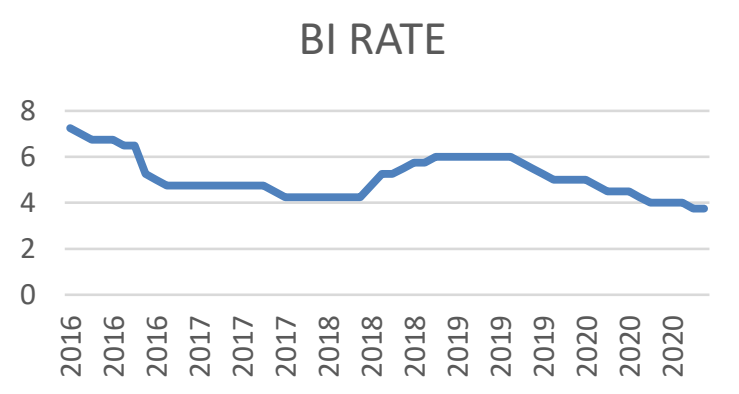

Gambar 5. Perkembangan BI Rate Indonesia Tahun 2016-2020

Sumber: Badan Pusat Statistik, data diolah (2021)

Gambar 5 menunjukkan $\mathrm{Bl}$ rate telah berfluktuasi dalam 5 tahun mengalami fluktuasi. Selama kurun waktu 5 tahun terakhir $\mathrm{BI}$ rate tertinggi pada bulan Januari 2016 mencapai 7,25 persen. Kemudian terus menurun hingga mencapai 4,25 persen pada April 2018. Inflasi pada pertengahan 2017 lebih rendah dari yang diharapkan merupakan alasan Bank Indonesia dalam menurunkan suku bunga acuan. Kedua, defisit transaksi berjalan (current account deficit/CAD) masih belum terkendali. Ketiga, meredanya dari arah kebijakan bank sentral AS Federal Reserve (The Fed). Terakhir, suku bunga yang menurun mendorong perbankan untuk menyalurkan kredit sehingga mendukung pertumbuhan ekonomi. 


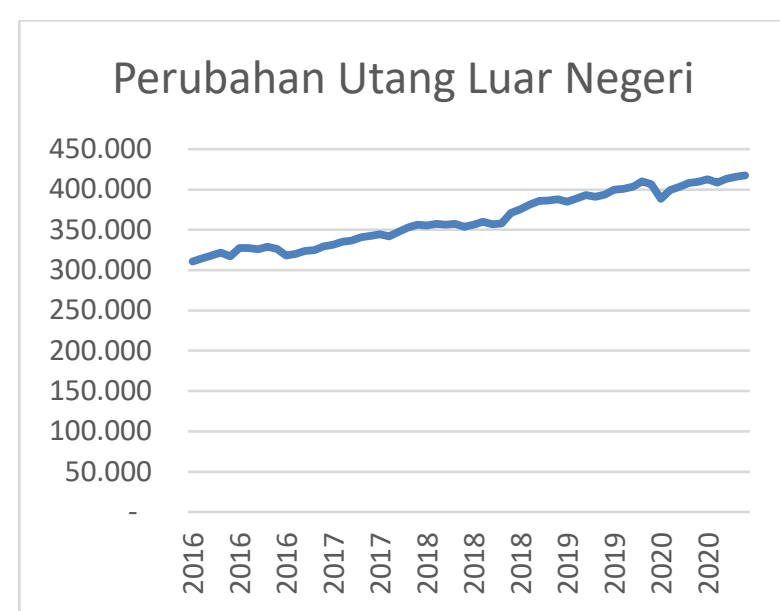

Gambar 6. Perkembangan Utang Luar Negeri Indonesia Tahun 2016-2020

Sumber: Badan Pusat Statistik, data diolah (2021)

Gambar 6 menunjukkan utang luar negeri yang dimiliki Indonesia dalam 5 tahun yang fluktuasi namun cenderung meningkat. Utang luar negeri terendah pada bulan Januari 2016 sebesar 310.737 miliar dolar US dan mengalami penurunan utang luar negeri swasta serta pertumbuhan yang mengalami perlambatan pertumbuhan dalam utang luar negeri publik. Namun Bank Indonesia tetap mewaspadai risiko yang akan dihadapi perekonomian agar utang luar negeri dapat berperan secara optimal dalam mendukung pembiayaan sehingga tidak berdampak pada stabilitas makroekonomi. Pinjaman luar ngeri mengalami peningkatan pada 2020 akibat dampak pandemic covid-19. Utang luar negeri tersebut digunakan untuk menyelamatkan perekonomian. Pada akhir tahun 2020, utang luar negeri mencapai 417,481 miliar dolar US.

\section{Error Correction Model (ECM) Uji Stasioneritas Data}

Uji akar unit (unit root test) dengan menggunakan uji akar unit Dickey-Fuller (DF) merupakan menguji data deret waktu apakah stationer atau tidak.

Tabel 1. Hasil Uji Akar Unit dengan Dickey-Fuller pada Tingkat Level dengan Intercept

\begin{tabular}{|c|c|c|c|c|}
\hline Variabel & $\begin{array}{l}\text { Adj t- } \\
\text { stat }\end{array}$ & $\begin{array}{c}\text { Cricital } \\
\text { Value } \\
5 \% \\
\end{array}$ & Prob & Ket \\
\hline Cad Dev & 2.0683 & -2.9117 & 0.2580 & $\begin{array}{c}\text { Tidak } \\
\text { stasioner }\end{array}$ \\
\hline Ekspor & $\begin{array}{c}- \\
2.5770\end{array}$ & -2.9126 & 0.1035 & $\begin{array}{c}\text { Tidak } \\
\text { stasioner }\end{array}$ \\
\hline Inflasi & $\begin{array}{c}- \\
1.2757\end{array}$ & -2.9117 & 0.6352 & $\begin{array}{c}\text { Tidak } \\
\text { stasioner }\end{array}$ \\
\hline BI Rate & $\begin{array}{c}- \\
1.8838\end{array}$ & -2.9126 & 0.3375 & $\begin{array}{c}\text { Tidak } \\
\text { stasioner }\end{array}$ \\
\hline ULN & $\begin{array}{c}- \\
0.4745\end{array}$ & -2.9117 & 0.8884 & $\begin{array}{c}\text { Tidak } \\
\text { stasioner }\end{array}$ \\
\hline
\end{tabular}

Berdasarkan hasil uji akar unit pada tabel 1 dapat disimpulkan bahwa semua variabel tersebut dinyatakan tidak stasioner karena nilai ADF $t$-statistic lebih rendah dibandingkan dengan nilai kritis MacKinnon atau dilihat dari nilai probabilitasnya yang lebih tinggi dari 0,05 atau tidak signifikan pada $\alpha=5 \%$. Karena data tidak stasioner pada tingkat level, sehingga dilanjutkan uji stasioneritas pada derajat integrasi first difference. Berikut ini adalah hasil uji stasioneritas pada tingkat first difference:

Tabel 2. Hasil Uji Akar Unit dengan Dickey-Fuller pada Tingkat 1st difference

\begin{tabular}{lcccc}
\hline Variabel & $\begin{array}{c}\text { Adj t- } \\
\text { stat }\end{array}$ & $\begin{array}{c}\text { Cricital } \\
\text { Value } \\
5 \%\end{array}$ & Prob & Ket \\
\hline Cad Dev & -8.6296 & - & 0.0000 & Stasioner \\
Ekspor & - & $\begin{array}{c}2.9126 \\
-\end{array}$ & 0.0000 & Stasioner \\
Inflasi & 14.6237 & 2.9126 & & \\
BI Rate & -7.2715 & - & 0.0000 & Stasioner \\
ULN & -5.4904 & $\begin{array}{c}2.9126 \\
-\end{array}$ & 0.0000 & Stasioner \\
& -8.2252 & - & 0.0000 & Stasioner \\
& \multicolumn{5}{c}{2.9126} \\
\hline \multicolumn{5}{c}{ Sumber: Hasil Olahan Eviews 10 }
\end{tabular}

Tabel 2 yaitu hasil uji stasioneritas pada tingkat $1^{\text {st }}$ difference dapat disimpulkan bahwa semua variabel tersebut dinyatakan stasioner karena ADF $t$-statistic lebih tinggi dibandingkan dengan nilai kritis MacKinnon atau bisa dilihat dari nilai probabilitas semua variabel yang signifikan pada $\alpha=5 \%$. Karena semua data telah stasioner pada tingkat $1^{\text {st }}$ difference, oleh karena itu 
memenuhi langkah selanjutnya dalam model ECM.

\section{Uji Kointegrasi}

Setelah semua variabel stasioner pada derajat yang sama yaitu pada $1^{\text {st }}$ difference, maka selanjutnya melakukan uji kointegrasi. Untuk mengetahui apakah data tersebut memiliki kointegrasi maka menggunakan uji kointegrasi dengan pendekatan Engel Granger.

Tabel 3. Hasil Uji Akar Unit dengan Dickey-Fuller pada Tingkat Level

\begin{tabular}{|c|c|c|c|c|c|c|}
\hline \multirow[t]{2}{*}{ Variabel } & \multirow{2}{*}{$\begin{array}{c}\text { Adj } \\
\mathrm{t}- \\
\text { stat }\end{array}$} & \multicolumn{3}{|c|}{$\begin{array}{l}\text { Nilai Kritis } \\
\text { MacKinnon }\end{array}$} & \multirow{2}{*}{$\begin{array}{c}\text { Prob } \\
.\end{array}$} & \multirow[t]{2}{*}{ Ket. } \\
\hline & & $1 \%$ & $5 \%$ & $10 \%$ & & \\
\hline ECT & $\begin{array}{c}- \\
4.20 \\
91\end{array}$ & $\begin{array}{c}- \\
3.54 \\
61\end{array}$ & $\begin{array}{c}- \\
2.91 \\
17\end{array}$ & $\begin{array}{c}- \\
2.59 \\
36\end{array}$ & $\begin{array}{c}0.00 \\
14\end{array}$ & Koint \\
\hline
\end{tabular}

Sumber: Hasil Olahan Eviews 10

Dari tabel 3 dapat disimpulkan bahwa variabel residual berkointegrasi atau memiliki hubungan jangka panjang karena nilai ADF t-statistic yaitu -4.2091 lebih tinggi dari nilai kritis MacKinnon pada tingkat signifikansi $\alpha=1 \%, \alpha=5 \%$ maupun $\alpha=10 \%$.

\section{Estimasi Persamaan Jangka Panjang}

Setelah data memiliki kointegrasi, maka langkah selanjutnya yaitu estimasi persamaan jangka panjang untuk menunjukkan bagaimana variabel bebas dalam mempengaruhi variabel terikat.

Tabel 4. Hasil Estimasi Jangka Panjang

\begin{tabular}{ccccc}
\hline $\begin{array}{c}\text { Variabl } \\
\mathrm{e}\end{array}$ & $\begin{array}{c}\text { Coefficie } \\
\mathrm{nt}\end{array}$ & $\begin{array}{c}\text { Std. } \\
\text { Error }\end{array}$ & $\begin{array}{c}\mathrm{t}- \\
\text { Statistic }\end{array}$ & Prob \\
\hline $\mathrm{C}$ & 81485.71 & 9265.01 & 9.79499 & 0.000 \\
& & 3 & 2 & 0 \\
Ekspor & - & 0.29158 & - & 0.785 \\
& 0.079705 & 7 & 0.27334 & 6 \\
& & & 9 & \\
Inflasi & 2374.046 & 820.650 & 2.89288 & 0.005 \\
& & 5 & 3 & 5 \\
BI Rate & - & 518.922 & - & 0.000 \\
& 5873.536 & 4 & 11.3187 & 0 \\
& & & 2 & \\
ULN & 0.178018 & 0.01831 & 9.71926 & 0.000 \\
& & 6 & 4 & 0 \\
\hline
\end{tabular}

\begin{tabular}{cc}
\hline R- & 0.886346 \\
square & \\
d & \\
F- & 107.2311 \\
statistic & \\
Prob. & 0.000000 \\
(F- & \\
statistic & \\
) & \\
\hline \multicolumn{3}{c}{ Sumber: Hasil Olahan Eviews 10}
\end{tabular}

Dari estimasi jangka panjang pada tabel 4 maka diperoleh persamaan jangka panjang sebagai berikut:

$Y_{t}=81485.71-0.079705 \mathrm{X} 1_{\mathrm{t}}+2374.046 \mathrm{X} 2_{\mathrm{t}}$ $-5873.536 \times 3_{t}+0.178018 \times 4_{t}+e$

Berdasarkan estimasi jangka panjang nilai probabilitas F-statistic sebesar 0,000 artinya secara simultan variabel ekspor, BI rate, inflasi, dan utang luar negeri memiliki pengaruh terhadap cadangan devisa. Hasil $R$-square menunjukkan sebesar 0.886346 yang artinya bahwa sebesar $89 \%$ variabel cadangan devisa dalam model ini dipengaruhi oleh variabel ekspor, inflasi, BI rate, dan Utang Luar Negeri. Serta sisanya sebesar $11 \%$ dipengaruhi oleh variabel lain diluar model.

Estimasi Error Correction Model (ECM) Berikut merupakan hasil estimasi Error Correction Model (ECM) atau estimasi jangka pendek dalam penelitian ini :

Tabel 5. Hasil Estimasi Error Correction Model (ECM)

\begin{tabular}{ccccc}
\hline $\begin{array}{c}\text { Variabl } \\
\mathrm{e}\end{array}$ & $\begin{array}{c}\text { Coefficie } \\
\mathrm{nt}\end{array}$ & $\begin{array}{c}\text { Std. } \\
\text { Error }\end{array}$ & $\begin{array}{c}\mathrm{t}- \\
\text { Statistic }\end{array}$ & Prob \\
\hline $\mathrm{C}$ & - & 293.528 & - & 0.137 \\
& 441.2052 & 2 & 1.50311 & \\
Ekspor & - & 0.19278 & - & 0.479 \\
& 0.137241 & 9 & 0.71187 & 7 \\
& & & 0 & \\
Inflasi & 88.23194 & 893.206 & 0.09878 & 0.921 \\
& & 2 & 1 & 7 \\
BI Rate & - & 1270.83 & - & 0.002 \\
& 4007.190 & 8 & 3.15318 & 7 \\
& & & 6 & \\
ULN & 0.440190 & 0.05910 & 7.44765 & 0.000 \\
& & 4 & 9 & 0 \\
ECT(- & - & 0.09565 & - & 0.001 \\
1) & 0.333511 & 2 & 3.48670 & 0 \\
& & & 9 & \\
\hline
\end{tabular}




\begin{tabular}{cc}
\hline R- & 0.611489 \\
square & \\
d & \\
F- & 16.68365 \\
statistic & \\
Prob. & 0.000000 \\
(F- & \\
statistic & \\
) & \\
\hline
\end{tabular}

Sumber: Hasil Olahan Eviews 10

Berdasarkan tabel 5 hasil estimasi jangka pendek atau ECM, maka diperoleh persamaan sebagai berikut :

$$
\begin{array}{rl}
\Delta Y_{t}=-441.205 & 205-0.13724 \Delta X 1_{t}+88.23194 \Delta X 2_{t} \\
& -4007.19 \Delta X 3_{t}+0.44019 \Delta X 4_{t} \\
& -0.33351 E C T(-1)+e_{t}
\end{array}
$$

Berdasarkan tabel 5 hasil estimasi

ECM menunjukkan nilai probabilitas ECT(-1) sebesar 0.010 yang artinya signifikan pada $\alpha=5 \%$ berarti model spesifikasi ECM yang digunakan dalam penelitian ini adalah valid. Nilai koefisien ECT(-1) menunjukkan bahwa cadangan devisa dengan nilai sebesar -0.333511 akan disesuaikan dalam waktu 3 bulanan atau model jangka pendek akan disesuaikan untuk mencapai keseimbangan jangka panjang. Nilai probabilitas dalam hasil ini sebesar 0,0000 yang artinya secara simultan ekspor, BI rate, inflasi, dan utang luar negeri mempengaruhi cadangan devisa Indonesia pada tahun 2016 - 2020. Hasil nilai $R$-square sebesar 0.611489 artinya bahwa $61 \%$ model perubahan cadangan devisa dipengaruhi oleh variabel ekspor, BI rate, inflasi, dan Utang Luar Negeri, serta sisanya sebesar $39 \%$ dipengaruhi oleh variabel lain diluar model.

\section{Pembahasan}

\section{Pengaruh Ekspor Terhadap Cadangan Devisa Tahun 2016 - 2020}

Berdasarkan hasil jangka panjang nilai probabilitas ekspor 0.7856 lebih tinggi dari taraf nyata $5 \%$ dan nilai koefisiennya $-0,079705$ sedangkan dalam jangka pendek (ECM) nilai probabilitasnya 0.4797 dengan koefisien 0,137241 artinya variabel ekspor secara parsial tidak memiliki pengaruh terhadap cadangan devisa Indonesia pada tahun 2016-2020. Nilai ekspor Indonesia sempat mengalami penurunan 27 persen dari bulan sebelumnya yaitu pada tahun 2016 dan adanya pandemi Covid-19 juga berakibat pada penurunan ekspor yang cukup tinggi dibandingkan sebelum pandemi Covid-19 karena ada pembatasan sosial dan penurunan daya beli. Hasil penelitian ini juga sejalan dengan penelitian sebelumnya yang telah dilakukan oleh Ardianti dan Swara (2018) yang menunjukkan bahwa variabel ekspor tidak memiliki pengaruh terhadap cadangan devisa, karena turunnya harga komoditas sektor migas, ekspor migas menurun, dan permintaan bahan bakar minyak yang terus meningkat menyebabkan nilai ekspor lebih rendah dibandingkan impor.

Pengaruh Inflasi Terhadap Cadangan Devisa Tahun 2016 - 2020

Berdasarkan estimasi jangka panjang, variabel impor memiliki pengaruh positif serta signifikan terhadap variabel cadangan devisa dari tahun 2016 sampai dengan 2020, dengan koefisien 2374,046 dan probabilitas 0,0055 . Setiap kenaikan tingkat inflasi 1 persen akan mengakibatkan kenaikan cadangan devisa sebesar 2374,046 miliar dolar US. Salah satunya dapat ditunjukkan melalui tingkat inflasi pada bulan Agustus 2019 yang mengalami kenaikan mampu menaikkan cadangan devisa menjadi 126.441 miliar dolar US. Sementara itu dalam estimasi ECM, variabel inflasi tidak memiliki pengaruh terhadap cadangan devisa, dikarenakan nilai probabilitasnya 0.9217 . Hal ini sesuai dengan penelitian sebelumnya yang telah dilakukan oleh Adiyadna (2017) yang menunjukkan bahwa inflasi tidak berdampak pada cadangan devisa dari tahun 1996 hingga 2015, karena nilai mata uang rupiah mengalami kenaikan atau terdepresiasi menyebabkan penurunan harga 
komoditas ekspor dan berdampak pada cadangan devisa.

\section{Pengaruh BI Rate terhadap Cadangan Devisa Pada Tahun 2016-2020}

Berdasarkan hasil estimasi jangka panjang menunjukkan nilai probabilitas 0,0000 dan koefisien sebesar $-5873,536$ sedangkan hasil estimasi ECM menunjukkan nilai probabilitas sebesar 0,0027 dan koefisien sebesar -4007,190. Oleh karena itu, variabel $\mathrm{Bl}$ rate dalam jangka panjang maupun jangka pendek berdampak negatif serta signifikan terhadap cadangan devisa pada tahun 2016 - 2020. Dalam jangka panjang setiap kenaikan 1 persen menurunkan 5873,536 miliar dolar rupiah dan dalam jangka pendek setiap kenaikan 1 persen menurunkan 4007,190 miliar dolar rupiah. Ini tidak sesuai dengan hipotesis awal yaitu kenaikan $\mathrm{BI}$ rate yang menaikkan cadangan devisa. Hal ini sesuai dengan penelitian sebelumnya yang telah dilakukan oleh Adiyadna (2017) dan Juliansyah (2020) yaitu setiap kenaikan $\mathrm{BI}$ rate akan berpengaruh terhadap penurunan cadangan devisa.

\section{Pengaruh Utang Luar Negeri terhadap Cadangan Devisa Tahun 2016 - 2020}

Berdasarkan estimasi jangka panjang, menunjukkan nilai probabilitas variabel utang luar negeri (ULN) kurang dari taraf nyata $5 \%$ dan koefisien 0,178018 yang artinya memiliki dampak yang positif serta signifikan terhadap cadangan devisa. Sedangkan estimasi ECM atau jangka pendek variabel utang luar negeri dengan probabilitas 0.000 kurang dari taraf nyata $5 \%$ dan koefisien sebesar 0,440190. Oleh karena itu, baik dalam perspektif jangka panjang maupun jangka pendek, variabel utang luar negeri memiliki dampak yang positif serta signifikan terhadap cadangan devisa yaitu setiap kenaikan 1 miliar dolar rupiah akan mempengaruhi peningkatan cadangan devisa. Salah satunya dapat dilihat pada tahun 2017 cadangan devisa dipengaruhi oleh peningkatan utang luar negeri. Hal ini sesuai dengan penelitian Adiyadna (2017), Ardianti (2017), dan Togatorop (2017) yang menunjukkan bahwa utang luar negeri berdampak positif dan signifikan terhadap cadangan devisa Indonesia, karena utang luar negeri dicatat dalam neraca modal Indonesia sehingga cadangan devisa meningkat (Adiyadnya, 2017; Ardianti \& Swara, 2018; Togatorop \& Setiawina, 2017).

\section{KESIMPULAN \& SARAN \\ Kesimpulan}

Berdasarkan hasil analisis Error Correction Model (ECM) yang telah dijelaskan sebelumnya, maka dapat tarik kesimpulan sebagai berikut:

1. Variabel ekspor, BI rate, inflasi, dan utang luar negeri dalam perspektif jangka pendek maupun jangka panjang secara bersama-sama berdampak terhadap cadangan devisa Indonesia dari tahun 2016 hingga 2020.

2. Keterkaitan variabel ekspor dan cadangan devisa dalam perspektif jangka pendek maupun jangka panjang adalah negatif tidak signifikan pada tahun 2016 - 2020 .

3. Dalam perspektif jangka pendek, variabel inflasi memiliki keterkaitan yang positif namun tidak signifikan terhadap cadangan devisa pada tahun 2016 - 2020, sedangkan dalam perspektif jangka panjang memiliki keterkaitan yang positif signifikan.

4. Dalam perspektif jangka pendek dan jangka panjang, terdapat keterkaitan antara variabel $\mathrm{BI}$ rate yang negatif signifikan terhadap cadangan devisa pada tahun 2016 - 2020 .

5. Dalam perspektif jangka pendek dan jangka panjang, memiliki hubungan negatif signifikan antara variabel utang luar negeri dan cadangan devisa dari tahun 2016 hingga 2020. 


\section{Saran}

Berdasarkan hasil penelitian yang berdampak signifikan terhadap cadangan devisa, maka terdapat beberapa saran yang dapat dipertimbangkan yaitu yang pertama sebaiknya pemerintah menggunakan utang luar negeri sebaik mungkin untuk keperluan produksi baik barang ataupun jasa yang berkualitas ekspor. Dengan adanya ekspor akan menambah pendapatan negara berupa valuta asing sehingga akan menambah cadangan devisa yang berasal dari ekspor. Kedua, pemerintah menjaga kestabilan suku bunga sehingga akan banyak investasi masuk untuk keperluan peningkatan produksi barang dan jasa ekspor yang akan menambah devisa Indonesia.

\section{Daftar Pustaka}

Adiyadnya, M. S. P. (2017). Suku Bunga Kredit Dan Utang Luar Negeri

Terhadap Cadangan Devisa Indonesia Tahun 1996-2015. Jurnal Riset Akuntansi, 7(1), 68-78.

Ardianti, D. A. M. Y., \& Swara, W. Y. (2018). Pengaruh Ekspor Neto , Kurs , Pdb Dan Utang Luar Negeri Terhadap Cadangan Devisa Indonesia 1997-2016. E-Jurnal Ekonomi Pembangunan Universitas Udayana, 7(6), 1199-1227.

Asyaria, K., Budiantoro, R. A., \& Herianingrum, S. (2020). Analisis

Neraca Perdagangan Migas dan Non Migas Terhadap. Jurnal Manajemen Dan Bisnis Indonesia, 6(1), 38-45.

BI. (2017). BI-7 Day Reverse Repo Rate (BI7DRR). Bank Indonesia. https://www.bi.go.id/id/fungsiutama/moneter/bi-7dayrr/default.aspx

BI. (2021). Cadangan Devisa Desember 2020
Meningkat. Bank Indonesia.

https://www.bi.go.id/id/publikasi / ruang-media/newsrelease/Pages/sp_230521.aspx

Deny, S. (2017). Agar Utang Luar Negeri Lebih Sehat, RI Perlu Tingkatkan Ekspor. Liputan6.Com.

https:/ / www.liputan6.com/bisnis/ $\mathrm{read} / 3115865 /$ agar-utang-luarnegeri-lebih-sehat-ri-perlutingkatkan-ekspor

Jalunggono, G., Cahyani, Y. T., \& Juliprijanto, W. (2020). Pengaruh Ekspor, Impor Dan Kurs Terhadap Cadangan Devisa Indonesia Periode Tahun 2004 - 2018. Jurnal Ekonomi, Bisnis, Dan Akuntansi, 22(2), 171-181. https:// doi.org/10.32424/jeba.v22i2 .1593

Juliansyah, H., Moulida, P., \& Apridar. (2020). Analisis Faktor-faktor Yang Mempengaruhui Cadangan Devisa Indonesia Bukti (Kointegrasi dan Kausalitas). Jurnal Ekonomi Regional Unimal, 3(2), 32-46.

http:/ /ojs.unimal.ac.id/index.php/ ekonomi_regional

Krugman, P., \& Obtfel, M. (2003).

Internasional Economics Theory And

Policy (London). Foresman And

Company.

Mankiw, N. G. (2000). Teori Makro Ekonomi (Edisi Keem). Erlangga.

Nopirin. (2012). Ekonomi Moneter Buku II (1st ed.). BPFE Yogyakarta.

Palembangan, I. T., Kumaat, R. J., Mandeij, D., Pembangunan, J. E., Ekonomi, F., \& Ratulangi, U. S. (2020). Analisis Pengaruh Tingkat Bunga Acuan Bi, Sibor, Dan Nilai Tukar Rupiah Terhadap Cadangan Devisa Di Indonesia (2011:Q12019:Q4). Jurnal Berkala Ilmiah Efisiensi, 20(02), 152-164.

Pransuamitra. (2021). Desember, Cadangan 
Devisa RI Tertinggi Kedua Sepanjang

Masa! CNBC Indonesia.

https://www.cnbcindonesia.com/

market/20210108114851-17-

214459/desember-cadangan-devisa-

ri-tertinggi-kedua-sepanjang-masa

Togatorop, S. M., \& Setiawina, N. D.

(2017). Pengaruh Utang Luar

Negeri, Net Ekspor, Dan Belanja

Wisatawan Mancanegara Terhadap

Cadangan Devisa Di Negara

Indonesia Tahun 1994-2013. E-Jurnal

Ekonomi Pembangunan Universitas

Udayana, 6(6), 1004-1032.

Ulya, N. F. (2021). Desember 2020, Posisi

Cadangan Devisa RI Naik Jadi 135,9

Miliar Dollar AS. Kompas.Com.

https://money.kompas.com/read/ 2021/01/08/110725026/desember2020-posisi-cadangan-devisa-rinaik-jadi-1359-miliar-dollaras\#: :text=Erwin mengungkap $\% 2 \mathrm{C}$ alasan cadangan devisa,negeri pemerintah dan penerimaan pajak.

Windarjono, A. (2018). Ekonometrika:

Pengantar dan Aplikasinya Disertai

Panduan Eviews. UPP STIM YKPN. 